\title{
Predation by snakes thwarts trial reintroduction of the Endangered woma python Aspidites ramsayi
}

\author{
J. L. REA D, G. R. JOHNSTON and T. P. MORLEY
}

\begin{abstract}
Case studies of well-documented snake reintroductions are limited, despite their potential value for conservation and ecosystem recovery. The Endangered woma Aspidites ramsayi is a large boid snake that has declined considerably and is now threatened throughout much of central Australia. We describe a trial release of captive-bred womas into the feral predator-free Arid Recovery Reserve in northern South Australia. All of the reintroduced womas were killed within 4 months, with predation by the mulga snake Pseudechis australis confirmed or implied in all cases. Lessons learned for the conditioning of captive-bred snakes for wild release and the role of the mulga snake in structuring Australian aridzone snake assemblages are discussed.
\end{abstract}

Keywords Arid zone, Aspidites ramsayi, Australia, elapid, predation, python, reintroduction, woma

\section{Introduction}

$\mathrm{R}$ eintroductions are widely recognized as integral to many species' conservation and ecosystem recovery initiatives (Fischer \& Lindenmayer, 2000; Seddon et al., 2007), despite most efforts failing to establish viable populations (Griffith et al., 1989; Dodd \& Seigel, 1991; Beck et al., 1994; Wolf et al., 1996). Despite playing an important role as predators in many environments and improved success rates for recent reintroductions (Germano \& Bishop, 2009), snake reintroductions are underrepresented in conservation management (Seddon et al., 2005). This paucity of snake reintroductions may be attributed to the low public interest in reptile conservation relative to birds and mammals. Furthermore, although comprehensive natural history or conservation status information has been integral to the success of two well-documented snake reintroductions (Tolson \& Garcia, 1997; Daltry et al., 2001) the lack of such information for many snake

J.L. READ (Corresponding author) Arid Recovery, G.P.O. Box 150, Roxby Downs, South Australia 5725, Australia, and School of Earth and Environmental Sciences, University of Adelaide, Adelaide, South Australia, Australia. E-mail john.read@adelaide.edu.au

G.R. Johnston School of Biological Sciences, Flinders University of South Australia, Adelaide, South Australia, Australia, and Zoos South Australia, Adelaide, South Australia, Australia

T.P. Morley Zoos South Australia, Adelaide, South Australia, Australia

Received 19 April 2010. Revision requested 17 June 2010.

Accepted 7 July 2010. First published online 31 August 2011. species (Dodd, 1987, 1993; Reinert, 1991) has hindered the implementation of snake reintroductions.

Experimental evidence suggests that translocated snakes move further, more erratically and exhibit lower survivorship than resident snakes (Fitch \& Shirer, 1971; Landreth, 1973; Galligan \& Dunson, 1979; Reinert \& Rupert, 1999; Plummer \& Mills, 2000; Butler et al., 2005). Behavioural changes that decrease survivorship of translocated snakes are accentuated for captive-bred individuals that may be less efficient at feeding or locating suitable refuges than wild-caught relocated animals (Plummer \& Mills, 2000; Mathews et al., 2005). Reintroduction success of captivebred snakes is therefore likely to be enhanced where prey populations are high, snake movements are contained, refuge sites from predators are plentiful and temperature extremes are limited.

The woma Aspidites ramsayi is an Australian boid snake that is thought to have declined because of habitat clearing in mesic environments and predation by feral domestic cats Felis catus and foxes Vulpes vulpes (Wilson \& Knowles, 1988; Pearson, 1993; Maryan, 2002). Although aborigines also hunt womas (Baker et al., 1993; Read, 2003) there is no evidence that this hunting has contributed to their decline. Predation by cats and foxes in concert with other factors has been implicated in driving many of the native mammalian prey species of womas to extinction or serious decline in the Australian arid zone (Johnson, 2006; McKenzie et al., 2007) and hence may represent both a direct and indirect threat to woma populations. Predation by dingoes Canis lupus dingo, or dogs Canis lupus familiaris has been significant for other arid-zone pythons (Heard et al., 2004) and hence could be a factor. The long-term viability of conservation programmes in degraded environments is compromised by re-establishment of a single threatened species in comparison to the recreation of more sustainable functioning ecosystems in which populations of reintroduced species are both enhanced and limited by biological factors (Seddon et al., 2007; Armstrong \& Seddon, 2008). Optimal conservation management and reintroduction sites for the woma should therefore experience nil or low cat, fox and dog predation and support as many of the natural potential prey species and ecosystem drivers as possible.

Here we describe an experimental reintroduction of captive-bred womas. Because the only available release animals were siblings, this reintroduction was considered a trial of the appropriateness of habitats, food availability, predator density and use of captive-bred pythons, rather 
than a genetically-robust reintroduction. Womas were released at a South Australian arid-zone site where introduced predators had been excluded and the native mammal fauna, including four successfully reintroduced species (greater stick-nest rat Leporillus conditor, burrowing bettong Bettongia lesueur, greater bilby Macrotis lagotis and western barred bandicoot Parameles bougainville) had made some recovery.

\section{Methods}

\section{The woma python}

The woma is a large $(\leq 3.0 \mathrm{~m})$ terrestrial python endemic to arid and semi-arid Australia. Womas are primarily nocturnal although they may occasionally be active by day (Fyfe \& Harvey, 1981; Maryan, 2002), and they have a catholic diet that includes rodents, bandicoots, other snakes, a variety of lizards, and birds (Fyfe \& Harvey, 1981; Shine \& Slip, 1990; Tyler et al., 1990; Covacevich \& Couper, 1996). Historically, womas made extensive use of bilby holes for shelter, and probably preyed on bilbies, resulting in the colloquial name bilby snake (Covacevich \& Couper, 1996). Following the reduction of native Australian burrowing mammals (Johnson, 2006) womas are known to have utilized warrens of introduced rabbits Oryctolagus cuniculus (GRJ \& JLR, unpubl. data). Despite this adaptation, woma abundance and distribution have declined to the extent that, notwithstanding the IUCN Red List categorization of the species as Endangered (Australasian Marsupial \& Monotreme Specialist Group, 1996), it is categorized as Critically Endangered in southern Western Australia (Cogger et al., 1993; Maryan, 2002), and Endangered or Vulnerable elsewhere in its range (Hutchinson, 1992; Sadlier, 1994; Covacevich \& Couper, 1996).

\section{The release site}

The Arid Recovery Reserve is a $60 \mathrm{~km}^{2}$ fenced exclosure in northern South Australia $\left(30^{\circ} 29^{\prime} \mathrm{S}, 136^{\circ} 53^{\prime} \mathrm{E}\right)$ from which all rabbits, cats and foxes have been removed (Moseby \& Read, 2006). Main habitats within the Reserve are linear orange sand dunes, vegetated by Acacia spp., Dodonaea viscosa and Zygochloa paradoxa, separated by sandy or stony clay swales vegetated by low chenopod shrubland. The Reserve lies within the known historical natural range of the woma. Road-killed womas have been collected $25 \mathrm{~km}$ south of the Arid Recovery Reserve on 10 October 1990 (South Australian Museum R41841) and $150 \mathrm{~km}$ north-west of the Reserve ( $30 \mathrm{~km}$ east of William Creek) on 25 February 2002. The failure of many attempts to reintroduce threatened Australian mammals has been attributed to predation by introduced predators (Short et al., 1992), hence the removal of cats and foxes has been integral to ecosystem recovery and reintroductions to the Reserve. Recovery of mammal populations at the Arid Recovery Reserve has occurred through natural increases following removal of introduced mammals (Moseby et al., 2009), and the successful reintroduction of locally extinct mammal species, including the bilby and another medium-sized burrowing species, the burrowing bettong (Read et al., 2008). In addition to developing a reintroduction protocol to improve the conservation status of womas, introduction of a native predator is an appropriate management initiative to limit burgeoning mammal populations within the Arid Recovery Reserve and to assist with the restoration of sustainable ecosystem processes.

\section{Origin of the stock and captive husbandry}

Ten captive-bred sibling womas derived from wild stock obtained close to the release site were chosen for the trial reintroduction. We considered regional provenance to be important because the woma exhibits considerable geographical variation in morphology (Morley, 1999). The dam and sire were donated to Adelaide Zoo from the Moomba area $\left(28^{\circ} 060^{\prime} \mathrm{S}, 140^{\circ} 11^{\prime} \mathrm{E}\right)$ and a road north of the Flinders Ranges, respectively. The sire was placed in the same enclosure as the dam at Adelaide Zoo on 12 April 2002 and mating was observed on 27 April 2002. Eighteen eggs were laid on 3 October 2002. Thirteen of the eggs hatched successfully but three of the resulting neonates subsequently died. Neonates weighed 16.6-52.3 g (mean 40.4 \pm SE $12.0 \mathrm{~g}$ ) and total lengths were $381-465 \mathrm{~mm}$ (mean $414 \pm \mathrm{SE} 37 \mathrm{~mm}$ ). The captive husbandry practices for womas at Adelaide Zoo have been described in detail by Morley (1999). Individual womas were identified using microchips (Trovan, Douglas, UK) placed under the skin on the left-hand side, just anterior to the cloaca.

Miniature radio-transmitters (SI-2, Holohil, Canada) were surgically implanted into the gut cavity on 3-5 April 2007. Surgical implantation of transmitters typically does not affect the health or behaviour of snakes (Slip \& Shine, 1988; Madsen \& Shine, 1996; Heard et al., 2004). Each transmitter weighed $11 \mathrm{~g}$, was $40 \times 11 \mathrm{~mm}$ with a $200 \mathrm{~mm}$ Teflon-coated antenna and a nominal life of 12-24 months. A $20-30 \mathrm{~mm}$ para-ventral incision was made $85-90 \%$ of the snout-vent length (SVL) from the snout under general anaesthesia using isoflourane. Transmitters were inserted into the gut cavity cranially and antennae inserted caudal to the incision. The gut cavity wall, muscle and skin were sutured with coated vicryl. Antibiotics (Batryl/Enrofloxan, Bayer Corp., Leverkusen, Germany) were applied subcutaneously at a dose of $10 \mathrm{mg} \mathrm{kg}^{-1}$ in a $1: 5$ saline solution every $48 \mathrm{~h}$ seven times following implantation. On the day of surgery snakes weighed 850-1,308 g (mean 1,032 \pm SE $140 \mathrm{~g}$ ) and had SVLs of 1,210-1,400 mm (mean 1,312 \pm SE $58 \mathrm{~mm}$ ). All snakes fed and sloughed their skin at least once following 
transmitter insertion before they were released. One transmitter failed and therefore only nine animals were released.

Prior to the release the incidence of endemic parasites and potential pathogens was investigated in reptiles from the Arid Recovery Reserve. During January-October 2005 23 individuals of seven species of lizard and two species of snake were investigated using cloacal swabs for bacteriology and faecal parasitology, and blood samples from live animals or histopathology following post mortem examination of road-kill specimens (Table 1). All womas identified for release were held in isolation from all other reptiles from May 2004 until release in September 2007. In addition to quarantining this extended period in captivity was designed to grow the pythons to a size where predation by potential native predators (mulga or king brown snake Pseudechis australis, Gould's goanna Varanus gouldii, brown falcon Falco berigora and wedge-tailed eagle Aquila audax) was less likely and the range of potential food items was increased. During this time they exhibited no symptoms of disease. We paid particular attention to the possibility of ophidian paramyxovirus or inclusion body disease. All released snakes were negative for DNA tests for paramyxovirus.

\section{Reintroduction and monitoring}

Two female and seven male womas, weighing 890-1,353 g (mean $=1,020 \pm$ SE $140 \mathrm{~g}$ ), were transported in calico bags inside foam boxes from Adelaide Zoo to Roxby Downs on 21 September 2007. The success of womas released directly into the Arid Recovery Reserve ('hard' release; 1 ㅇ 4 $\hat{\jmath}$ ) was intended to be compared with individuals released in a pen within the Reserve ('soft' release; 1 ㅇ $3{ }^{\uparrow}$ ). The 0.5 ha pen was surrounded by a $900-\mathrm{mm}$ high fence of $10-\mathrm{mm}$ diameter wire netting into which non-viable, weed-free oats were spread for 5 weeks before the release and weekly thereafter to encourage high rodent densities, principally Notomys alexis, Pseudomys bolami and Mus musculus. However, all four womas breached the release-pen fence within 2 months and hence comparisons of release techniques were abandoned.

Each woma was released adjacent to a disused bilby burrow on the morning of 22 September 2007. Released womas were observed for up to 4 hours until they had retreated to shelter, generally a burrow. Following release the womas were radio-tracked daily to determine their location, habitat, health and details of retreats used. We

TABLE 1 Endemic pathogens and parasites recorded from reptiles collected in the vicinity of the Arid Recovery Reserve (Fig. 1), where the womas were subsequently released.

\begin{tabular}{|c|c|c|c|}
\hline Species (by Family) & $\mathrm{n}$ & Test & Result \\
\hline \multicolumn{4}{|l|}{ Agamidae } \\
\hline Ctenophorus nuchalis & 3 & Blood smears & Nil \\
\hline Pogona vitticeps & 2 & Blood smears & $\begin{array}{l}\text { ?Haemoproteus sp. } \\
\text { in one animal }\end{array}$ \\
\hline Tympanocryptis intima & 4 & Blood smears & Nil \\
\hline \multicolumn{4}{|l|}{ Gekkonidae } \\
\hline Diplodactylus conspicillatus & 2 & Blood smears & Nil \\
\hline \multicolumn{4}{|l|}{ Scincidae } \\
\hline Ctenotus regius & 2 & Blood smear & Nil \\
\hline Tiliqua rugosa & 1 & Cloacal swab & Nil \\
\hline \multicolumn{4}{|l|}{ Varanidae } \\
\hline \multirow[t]{6}{*}{ Varanus gouldii } & 3 & Cloacal swab & Nil \\
\hline & & Histopathology & $\begin{array}{l}\text { Unidentified ticks \& } \\
\text { nematodes }\end{array}$ \\
\hline & & Cloacal swab & Nil \\
\hline & & Histopathology & Nil \\
\hline & & Cloacal swab & $\begin{array}{l}\text { Salmonella; heavy growth } \\
\text { of } E \text {. coli and Salmonella spp. }\end{array}$ \\
\hline & & Histopathology & $\begin{array}{l}\text { Unidentified ticks \& } \\
\text { nematodes }\end{array}$ \\
\hline \multicolumn{4}{|l|}{ Elapidae } \\
\hline \multirow[t]{4}{*}{ Pseudonaja sp. } & 4 & Cloacal swab & $\begin{array}{l}\text { Heavy growth of } \\
\text { Pseudomonas aeroginosa }\end{array}$ \\
\hline & & Histopathology & $\begin{array}{l}\text { Multiple duodenal ulcers } \\
\text { associated with embedded } \\
\text { unidentified nematodes }\end{array}$ \\
\hline & & Blood smear & Nil \\
\hline & & Cloacal swab & Salmonella Chester \\
\hline Pseudechis australis & 2 & Cloacal swab & Heavy growth of $P$. aeroginosa \\
\hline
\end{tabular}


deliberately located snakes at different times of the day to maximize the diurnal range of observations but found that we were not able to locate nocturnal fixes with precision or confidence without potentially damaging the refuges. Therefore most radio-tracking was conducted during daylight hours. Any tracks of womas and other animals found within $1 \mathrm{~m}$ of each woma shelter site were recorded when weather conditions permitted, allowing interpretation of woma activity patterns and potential prey or predator interactions. Following each visit to a refuge site all traces were obliterated by sweeping the sand so that woma and other animal activity could be assessed on a daily basis.

\section{Statistical analysis}

The distances travelled by womas and any mulga snakes that subsequently consumed them were compared using the Mann-Witney $U$ test to explore the nature of potential interactions between the species. A mixed model two-way ANOVA was used to compare the frequency with which tracks of different animals were recorded near woma refuges. A $\chi^{2}$ test was used to compare refuges (burrows, under vegetation, open surface) used by womas with that expected under a random distribution. All statistics were calculated using SPSS v. 15.o (SPSS, Chicago, USA).

\section{Results}

The most noteworthy outcome of this study was that all released woma pythons were dead between 41 and 123 days following release, either definitely or most likely killed by mulga snakes. Three python mortalities were attributed to at least two, probably three, different mulga snakes. Two of these womas were eaten by different mulga snakes that continued to be radio-tracked until they excreted their transmitters 33 and 23-27 days later. The other woma (\#98) was observed being repeatedly struck and dragged around by a mulga snake but was not swallowed (Plate 1). Three other womas were most likely killed by mulga snakes that were observed entering woma burrows immediately before their death (\#97) or they were located near death or dead with severe bruising and/or heart and lung damage consistent with mulga snake envenomation (\#91 and \#95). Two other womas (\#93 \& \#96) were removed from burrows in a decomposed state several days after many snake tracks were observed at the burrow, consistent with the sign left by a confirmed mulga snake attack followed by regurgitation of the woma. The final woma transmitter (\#99) was lost after it had moved widely on a swale for several days without being sighted, which was consistent with the movements of both mulga snakes known to have consumed womas (see below). We assume that this woma was swallowed by a mulga snake shortly before the longdistance movements of its transmitter commenced.

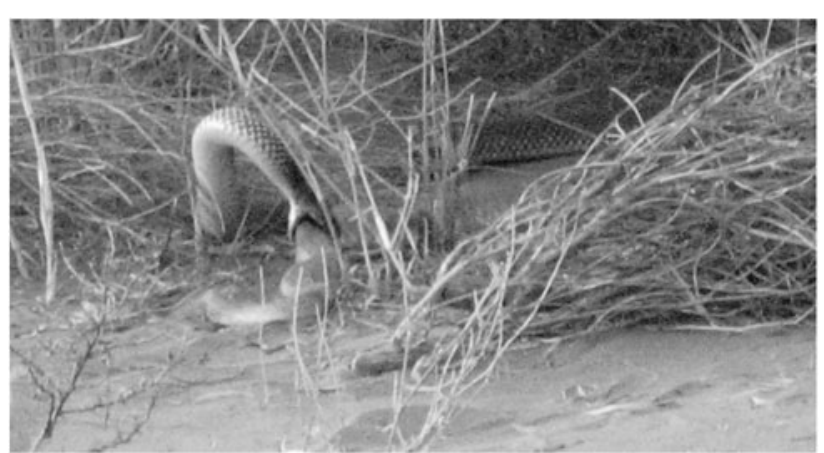

Plate 1 Mulga snake Pseudechis australis biting a reintroduced woma Aspidites ramsayi at the Arid Recovery Reserve in South Australia (Fig. 1). Photograph: Chris McGoldrick.

With the exception of moribund animals that had recently been attacked by mulga snakes, none of the womas appeared emaciated or unhealthy whenever they were observed directly during the trial. Successful feeding was confirmed for \#91, which contained substantial fat bodies during necropsy following its death 101 days after release. When captured 77 days after its initial release \#94 had lost $24 \%$ of its release mass. Despite this loss it defecated, suggesting it had fed since being released. Animal \#95 lost $27 \%$ of its release weight after 112 days and a further $10 \%$ over the next 11 days until it was killed but was not considered to be emaciated upon necropsy.

All womas remained in their initial shelter for 6-52 days (mean $=28 \pm$ SE 19 days, $n=9$ ). On several occasions during this initial sedentary period individuals were observed near the entrance of the shelter or short tracks were observed, suggesting the snakes may have been basking. Womas were located 38-99 times following release (mean $=68 \pm \mathrm{SE}$ 19 days, $n=9$ ). Following an initial sedentary period the womas moved shelters on average every 5.2 days (2.9-8.8 days) and individuals travelled a mean minimum distance of 15-227 m between consecutive refuges. Woma pythons moved significantly shorter minimum distances $(109 \pm$ SE $20 \mathrm{~m}, \mathrm{n}=68)$ than three radio-tracked mulga snakes (243 \pm SE $80 \mathrm{~m}, \mathrm{n}=13$; Mann-Whitney $U=281, \mathrm{P}=0.033$ ).

Of the 68 woma shelter sites located, 35 (51\%) were on dune crests, $32(47 \%)$ were on dune flanks and one was on a swale adjacent to a dune base (Fig. 1). The snakes also showed a clear pattern in the kind of refuge they used $\left(\chi_{2}^{2}=74.9, \mathrm{P}=0.000\right)$. Fifty-six $(82 \%)$ shelter sites were burrows or warrens, $10(15 \%)$ were in undergrowth, mainly canegrass Zyglochoa paradoxa, and two (3\%) were underground with no burrow evident. Burrows used included five hopping mouse Notomys alexis pop holes c. $60 \mathrm{~mm}$ in diameter, six goanna burrows c. $135 \times 75 \mathrm{~mm}$ in size, and 25 were bilby or bettong burrows, typically with a burrow entrance of $200-250 \times 150 \mathrm{~mm}$.

There were significant differences in potential dietary species' tracks recorded at woma refuges $\left(\mathrm{F}_{4,28}=49.884\right.$, 


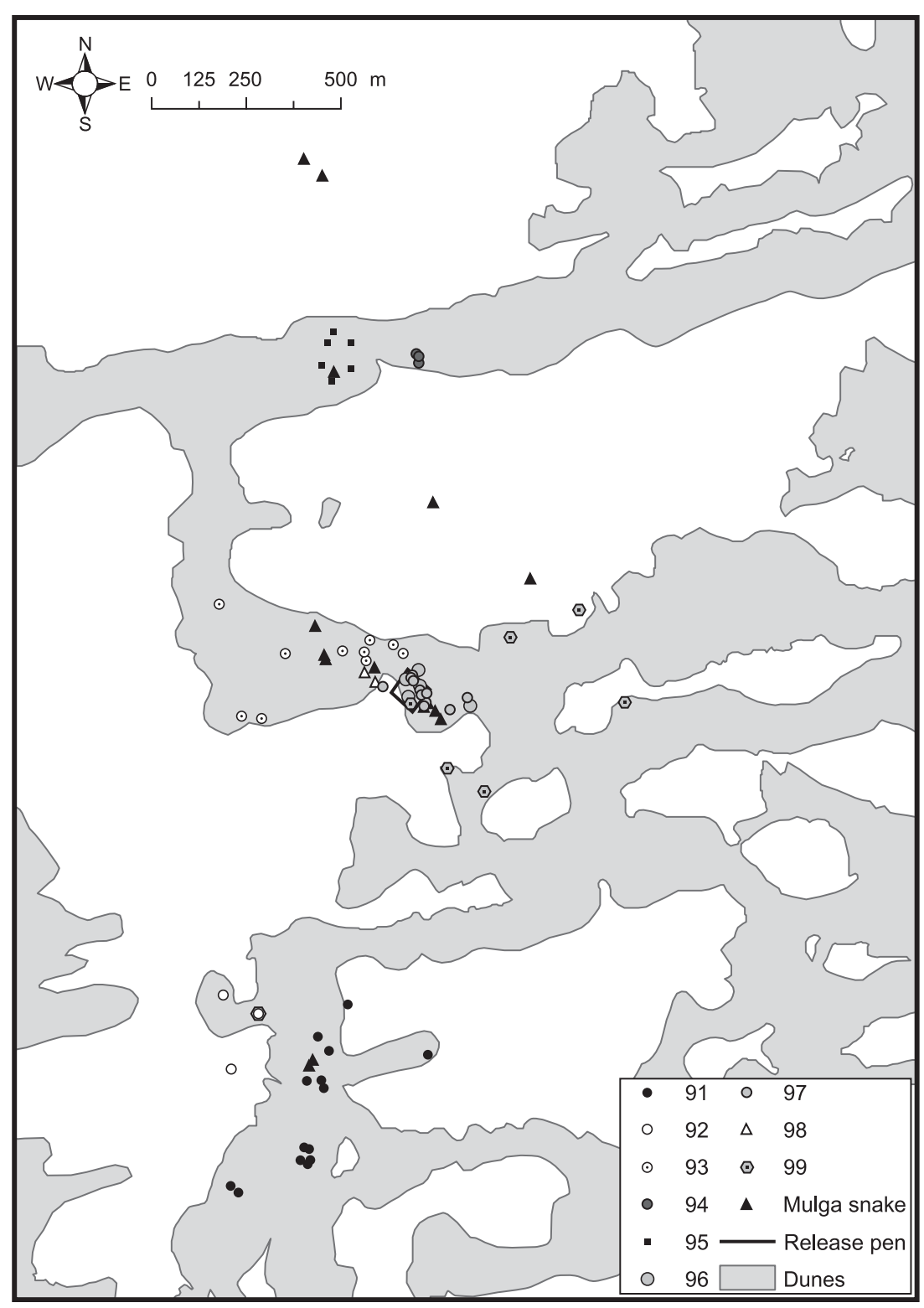

FIG. 1 Map of part of the Arid Recovery Reserve showing locations where nine woma pythons Aspidites ramsayi (\#91-99), and subsequently mulga snakes Pseudechis australis that predated three pythons, were found.
$\mathrm{P}=0.000$ ), with rodent tracks (70.4 \pm SE $3.8 \%$ ) occurring more frequently than all other kinds of tracks (Fig. 2). This suggests that womas in both release groups had access to ample potential prey.

\section{Discussion}

The key outcome of this trial release was that captive-bred womas were rapidly eaten or killed by mulga snakes when released into the wild. This finding presents a significant challenge for snake reintroductions wherever mulga snakes occur in arid and tropical Australia. Predation by native or introduced predators is a key contributing factor to many reintroduction failures (Short et al., 1992; Griffin et al., 2000). Prior to this study we assumed that predation by feral cats and foxes posed the main risk for woma pythons and that their removal would have facilitated the woma reintroduction, as it had for the successful reintroduction of four mammal species vulnerable to predation. We also incorrectly assumed, based on the work of King \& Stanford (2006), that we had minimized the potential for predation by raptors and large reptiles to thwart the woma reintroduction by waiting for the womas to reach in excess of $850 \mathrm{~g}$ before release. King \& Stanford (2006) found that plains garter snakes Thamnophis radix incubated and raised in captivity exhibited greater survival, particularly when released as large snakes, compared to wild-hatched garter snakes.

Further research with reintroduced predator-trained captive snakes, relocated wild snakes and in situ snake 


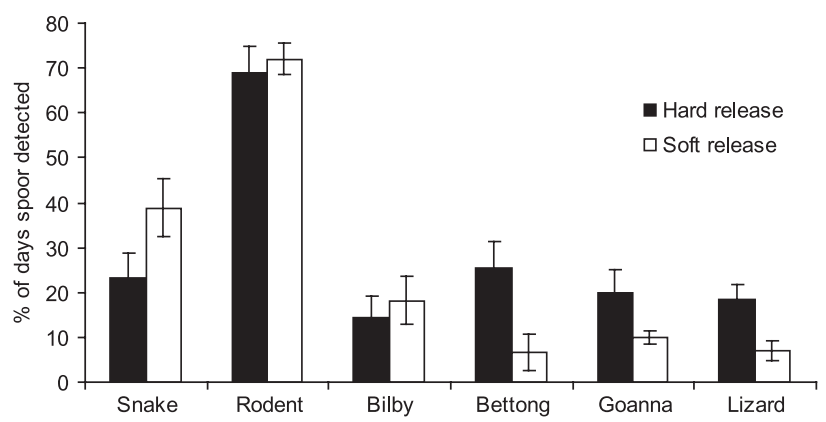

FIG. 2 Percentage of days that tracks of snakes (including womas), rodents, bilbies Macrotis lagotis, burrowing bettongs Bettongia lesueur, goannas Varanus gouldii and small lizards were recorded in or immediately adjacent to occupied refuges of 'hard' and 'soft' released (see text for details) womas.

populations is required to determine whether the vulnerability of womas to mulga snakes reported here indicate that mulga snakes significantly limit wild woma populations. Alternative hypotheses for the high predation include the naivety of the captive-bred snakes to predators or that mulga snake abundance or behaviour within the Arid Recovery Reserve during the trial release was atypical. Pre-release training has the potential to enhance the expression of pre-existing anti-predator behaviour in captive bred animals (Miller et al., 1990; McLean et al., 1996; Griffin et al., 2000). Often this training involves learning from the behaviour of conspecifics (Curio, 1988; Mineka \& Cook, 1988). Perhaps because reptiles are seldom social and do not exhibit maternal care, pre-release training and postrelease provisioning is less commonly used for reptile reintroductions compared to those of mammals or birds (Beck et al., 1994; Griffith et al., 1989).

The vulnerability of the reintroduced woma pythons to predation was perhaps accentuated by their inexperience with feeding and seeking optimal refuges. Captive-bred animals may be less efficient at capturing prey than wildcaught animals (Mathews et al., 2005). For instance, captive-bred hognose snakes Heterodon platirhinos experienced higher mortalities than wild-raised individuals because of failure to find appropriate hibernation sites (Plummer \& Mills, 2000).

Although lessons learned from both successful and failed translocations are integral to improving applied conservation management, many potentially valuable reintroduction attempts have not been documented in the peer-reviewed scientific literature (Fischer \& Lindenmayer, 2000). Deficiencies in documenting reintroduction performance is biased towards birds and mammals (Bajomi et al. 2009), thus increasing the value of reptile case studies. This woma reintroduction study revealed that intensively monitored trial releases can provide valuable information on the natural history of the target species and also improve methods for successful establishment of new populations.
Future reintroduction of womas, and potentially other pythons, to regions inhabited by mulga snakes, should consider reducing their vulnerability by using larger individuals accustomed to predators, either wild-raised or trained. Mulga snake densities could also be reduced during the initial phase of the reintroduction, although the estimation of actual, natural or appropriate mulga snake densities is problematical because of their cryptic nature and long periods of inactivity.

The high incidence of deaths inflicted by mulga snakes, which are relatively abundant and widespread across much of arid and tropical Australia, raises a number of questions about snake ecology in arid Australia. Given that mulga snakes are widespread and typically abundant throughout much of mainland Australia, what role does their predation or envenomation play in structuring snake assemblages and what conditions are necessary for successful recruitment of vulnerable species? Although cats kill c. 700 lizards $\mathrm{km}^{-2}$ each year in the Roxby region (Read \& Bowen, 2001), secondary trophic relationships, including an increase in varanids following removal of foxes and cats, may have contributed even more to the reduced reptile abundance apparent within the Arid Recovery Reserve (Moseby et al., 2009; Read \& Cunningham, 2010). Our study raises the possibility that mulga snakes may also be contributing to the suppression of reptile, especially other snake, populations in the Reserve. In at least five of the nine mulga snake/ woma interactions the mulga swallowed the woma and hence predation was probably the key motivation for the killing. However, at least two of the womas were killed by mulga snakes but not swallowed. These cases may represent failed predation attempts because the prey proved to be too large. The death rate may therefore have been reduced had more pythons been translocated and the local mulga snakes, which had not previously encountered reptilian prey too large to swallow, learned their limitations. Alternatively, the mulga snakes may have attacked the womas because they perceived them to be either a direct threat or potential competitors.

\section{Acknowledgements}

Arid Recovery partners and staff are thanked for their support and provision of the landscape-scale reintroduction and research site. Zoos South Australia staff are acknowledged for breeding, husbandry and veterinary work. Friends of Arid Recovery and Zoowatch volunteers (particularly Jennifer Hayes), and staff of Arid Recovery and Zoos South Australia assisted with post-release monitoring. Helen Crisp prepared Fig. 1. Dave Pearson and anonymous referees provided constructive criticism. Funding was provided by the Royal Zoological Society of South Australia, the Arid Recovery Project, the 
Australian Government Envirofund \& BHP Billiton. This project was approved (6/2005) by the Wildlife Ethics Committee of South Australia.

\section{References}

Armstrong, D.P. \& Seddon, P.J. (2008) Directions in reintroduction biology. Trends in Ecology \& Evolution, 23, 20-25.

Australasian Marsupial \& Monotreme Specialist Group (1996) Aspidites ramsayi. In IUCN Red List of Threatened Species $v$. 2010.4. Http://www.iucnredlist.org [accessed 9 February 2011].

Bajomi, B., Pullin, A.S., Stewart, G.B. \& Takas-Santa, A. (2010) Bias and dispersal in the animal reintroduction literature. Oryx, 44, 358-365.

Baker, L., Woenne-Green, S. \& The Mutitjulu Community (1993) Anangu knowledge of the vertebrates and the environment. In The Distribution and Abundance of Vertebrate Fauna of Uluru National Park (eds J.R.W. Reid, J.A. Kerle \& S.R. Morton), pp. 79-132. Australian National Parks and Wildlife Service, Canberra, Australia.

Beck, B.B., Rapaport, L.G., Stanley Price, M.R. \& Wilson, A.C. (1994) Reintroduction of captive born animals. In Creative Conservation: Interactive Management of Wild and Captive Animals (eds P.J.S. Olney, G.M. Mace \& A.T.C. Feistner), pp. 265-286. Chapman and Hall, London, UK.

Butler, H., Malone, B. \& Clemann, N. (2005) Activity patterns and habitat preferences of translocated and resident tiger snakes (Notechis scutatus) in a suburban landscape. Wildlife Research, 32, 157-163.

Cogger, H.G., Cameron, E.E., Sadlier, R.A. \& Eggler, P. (1993) The Action Plan for Australian Reptiles. Australian Nature Conservation Agency, Canberra, Australia.

Covacevich, J.A. \& Couper, P.J. (1996) Aspidites ramsayi (Boidae) in the Brigalow Biogeographic region of Queensland: occurrence, conservation status and possible bilby associations. Memoirs of the Queensland Museum, 39, 243-246.

Curio, E. (1988) Cultural transmission of enemy recognition by birds. In Social Learning: Psychological and Biological Perspectives (eds T.R. Zentall \& B.G. Galef, Jr), pp. 75-97. Lawrence Erlbaum Associates, Hillsdale, USA.

Daltry, J.C., Bloxam, Q., Cooper, G., Day, M.L., Hartley, J., Henry, M. et al. (2001) Five years of conserving the 'world's rarest snake', the Antiguan racer Alsophis antiguae. Oryx, 35, $119-127$

DodD, C.K. (1987) Status, conservation, and management. In Snake Ecology and Evolutionary Biology (eds R.A. Seigel, J.T. Collins \& S.S. Novak), pp. 478-513. Macmillan, New York, USA.

DodD, C.K. (1993) Strategies for snake conservation. In Snakes: Ecology and Behavior (eds R.A. Seigel \& J.T. Collins), pp. 363-393. McGraw-Hill, New York, USA.

Dodd, C.K. \& SeIgeL, R.A. (1991) Relocation, repatriation, and translocation of amphibians and reptiles: are they conservation strategies that work? Herpetologica, 47, 336-350.

Fischer, J. \& Lindenmayer, D.B. (2000) An assessment of the published results of animal relocations. Biological Conservation, 96, 1-11.

Fitch, H.S. \& Shirer, H.S. (1971) A radio-telemetric study of spatial relationships in some common snakes. Copeia, 1971, 118-128.

FyFE, G. \& HARVEY, C. (1981) Some observations on the woma (Aspidites ramsayi) in captivity. Herpetofauna, 13, 23-25.

Galligan, J.H. \& Dunson, W.R. (1979) Biology and status of timber rattlesnake (Crotalus horridus) populations in Pennsylvania. Biological Conservation, 15, 13-58.
Germano, J.M. \& Bishop, P.B. (2009) Suitability of amphibians and reptiles for translocation. Conservation Biology, 23, 7-15.

Griffin, A.S., Blumstein, D.T. \& Evans, C.S. (2000) Training captive-bred or translocated animals to avoid predators. Conservation Biology, 14, 1317-1326.

Griffith, B., Scott, J.M., Carpenter, J.W. \& Reed, C. (1989) Translocation as a species conservation tool: status and strategy. Science, $245,477-480$.

Heard, G.W., Black, D. \& Robertson, P. (2004) Habitat use by the inland carpet python (Morelia spilota metcalfei: Pythoninae): seasonal relationships with habitat structure and prey distribution in a rural landscape. Austral Ecology, 29, 446-460.

Hutchinson, M.N. (1992) Threatened reptiles in South Australia. In Threatened Species and Habitats in South Australia. A Catalyst for Community Action (ed. S.P. Tay). South Australian Advisory Committee on Threatened Species, Adelaide, Australia.

Johnson, C. (2006) Australia's Mammal Extinctions. Cambridge University Press, Melbourne, Australia.

KING, R.B. \& STANFORD, K.M. (2006) Headstarting as a management tool: a case study of the plains gartersnake. Herpetologica, $62,282-292$.

LANDRETH, H.F. (1973) Orientation and behavior of the rattlesnake, Crotalus atrox. Copeia, 1973, 26-31.

Madsen, T. \& Shine, R. (1996) Seasonal migration of predators and prey-a study of pythons and rats in tropical Australia. Ecology, $77,149-156$.

Maryan, B. (2002) Status of the woma, Aspidites ramsayi, in southwest Western Australia. Western Australia Naturalist, 23, 167-172.

McKenzie, N.L., Burbidge, A.A., Baynes, A., Brereton, R.N., Dickman, C.R., Gordon, G. et al. (2007) Analysis of factors implicated in the recent decline of Australia's mammal fauna. Journal of Biogeography, 34, 597-611.

McLean, I.G., Lundie-Jenkins, G. \& Jarman, P.J. (1996) Teaching an endangered mammal to recognize predators. Biological Conservation, 87, 123-130.

Mathews, F., Orros, M., Mclaren, G., Gelling, M. \& Foster, R. (2005) Keeping fit on the ark: assessing the suitability of captive bred animals for release. Biological Conservation, 121, 569-577.

Miller, B., Biggins, D., Wemmer, C., Powell, R., Calvo, L., Hanebury, L. \& Wharton, T. (1990) Development of survival skills in captive raised Siberian polecats (Mustela eversmanni) II. Predator avoidance. Journal of Ethology, 8, 95-104.

Mineka, S. \& Cook, M. (1988) Social learning and the acquisition of snake fear in monkeys. In Social Learning: Psychological and Biological Perspectives (eds T.R. Zentall \& B.G. Galef, Jr), pp. 51-73. Lawrence Erlbaum Associates, Hillsdale, USA.

Morley, T.P. (1999) Woma, Aspidites ramsayi. Taxon Management Account. Reptile Taxon Advisory Group of the Australasian Regional Association of Zoological Parks and Aquaria, Sydney, Australia.

Moseby, K.E., Hill, B.M. \& Read, J.L. (2009) Arid recovery-a comparison of reptile and small mammal populations inside and outside a large rabbit, cat and fox-proof exclosure in arid South Australia. Austral Ecology, 34, 156-169.

Moseby, K.E. \& Read, J.L. (2006) The efficacy of feral cat, fox and rabbit exclusion fence designs for threatened species protection. Biological Conservation, 127, 429-437.

Pearson, D.J. (1993) Distribution, status and conservation of pythons in Western Australia. In Herpetology in Australia. A Diverse Discipline (eds D. Lunney \& D. Aters), pp. 383-395. Royal Zoological Society of New South Wales, Sydney, Australia.

Plummer, M.V. \& Mills, N.E. (2000) Spatial ecology and survivorship of resident and translocated hognose snakes (Heterodon platirhinos). Journal of Herpetology, 34, 565-575. 
Rea D, J.L. (2003) Red Sand, Green Heart: Ecological Adventures in the Outback. Lothian, Melbourne, Australia.

Read, J. \& Bowen, Z. (2001) Population dynamics, diet and aspects of the biology of feral cats and foxes in arid South Australia. Wildlife Research, 28, 195-203.

Read, J.L., Carter, J., Moseby, K.E. \& Greenville, A. (2008) Ecological roles of rabbit, bettong and bilby warrens in arid Australia. Journal of Arid Environments, 72, 2124-2130.

Read, J.L. \& Cunningham, R. (2010) Relative impacts of cattle grazing and feral animals on an Australian arid zone reptile and small mammal assemblage. Austral Ecology, 35, 314-324.

REINERT, H.K. (1991) Translocation as a conservation strategy for amphibians and reptiles: some comments, concerns and observations. Herpetologica, 47, 257-363.

ReineRT, H.K. \& RUPERT, JR, R.R. (1999) Impacts of translocation on behavior and survival of timber rattlesnakes, Crotalus horridus. Journal of Herpetology, 33, 45-61.

SADLIER, R.A. (1994) Conservation status of the reptiles and amphibians in the western division of New South Wales-an overview. In Future of the Fauna of Western New South Wales (eds D. Lunney, S. Hand, P. Reed \& D. Butcher), pp. 161-167. The Royal Society of New South Wales, Sydney, Australia.

Seddon, P.J., Armstrong, D.P. \& Maloney, R.F. (2007) Developing the science of reintroduction biology. Conservation Biology, 21, 303-312.

Seddon, P.J., Soorae, P.S. \& Launay, F. (2005) Taxonomic bias in reintroduction projects. Animal Conservation, 8, 51-58.

Shine, R. \& S Lip, D.J. (1990) Biological aspects of the adaptive radiation of Australasian pythons (Serpentes: Boidae). Herpetologica, 46, 283-290.

Short, J., Bradshaw, S.D., Giles, J., Prince, R.I.T. \& Wilson, G.R. (1992) Reintroduction of macropods (Marsupialia: Macro- podoidea) in Australia-a review. Biological Conservation, 62, 189-204.

Slip, D.J. \& Shine, R. (1988) Habitat use, movements and activity patterns of free-ranging diamond pythons, Morelia spilota spilota (Serpentes: Boidae): a radio-telemetric study. Australian Wildlife Research, 15, 515-531.

Tolson, P.J. \& Garcia, M.A. (1997) Mona/Virgin Island Boa: A U.S./Puerto Rico Partnership Seeks to Recover Endangered Boa. American Zoos Association Species Survival Plan. Http:// www.umich.edu/ esupdate/library/97.01-02/tolson.html [accessed 19 January 2004].

Tyler, M.J., Edwards, A. \& Johnston, G.R. (1990) Amphibians and reptiles. In Natural History of the North East Deserts (eds M.J. Tyler, C.R. Twidale, M. Davies \& C.B. Wells), pp. 183-188. Royal Society of South Australia, Adelaide, Australia.

Wilson, S.K. \& Knowles, D.G. (1988) Australia's Reptiles. Collins, Sydney, Australia.

Wolf, C.M., Griffith, B., Reed, C. \& Temple, S.A. (1996) Avian and mammalian translocations: update and reanalysis of 1987 survey data. Conservation Biology, 10, 1142-1154.

\section{Biographical sketches}

JOHN READ is an ecologist with a particular research interest in reptiles and was a co-founder of Arid Recovery, a programme that aims to restore ecosystem functioning of an Australian arid-zone environment. GREG JOHNSTON is a wildlife biologist with an interest in behavioural ecology, evolution and conservation. TERRY MORLEY is a herpetologist and zoo keeper with a particular interest in the captive husbandry and conservation of reptiles. 